\title{
Plants collected by Gédéon Bonivert (1651-1703) in the garden of Johan Stickers (1630-1701)
}

\author{
By D.O. WIJNANDS
}

Botanical Gardens,

Agricultural University Wageningen,

P.O. Box 8010,

6700 ED Wageningen,

The Netherlands.

\begin{abstract}
Herbarium specimens preserved in the Sloane Herbarium (British Museum (Natural History), London) bear witness to the existence of a seventeenth century garden with exotic plants owned by Johan Stickers, apothecary at Breda. These specimens were collected by Gédéon Bonivert, an officer in the army of Stadtholder-King William III.
\end{abstract}

In 1665 Johan Stickers had established himself as apothecary in "De Witte Pluym" at the Grote Markt in Breda. In 1669 he bought a garden at the Gasthuiseinde, where he must have grown herbs. This purchase was followed by many others. In and around Breda, Stickers and his wife Anneken Geerit Claess de Gruyter acquired a number of houses, grounds, landed estates, meadows, orchards, and farms. In 1684 Stickers sold the garden on the Gasthuiseinde, but he retained a number of other estates where he could continue to grow medicinal herbs. In 1669 the Hortus Medicus of the Illustrious School at Breda was dissolved. This garden had been founded in 1646 by Johannes Brosterhuyen. After his death, in 1650, the English minister Samuel Johnson looked after the garden until 1653. Subsequently, the gardener Van Bosheyden took care of it until, in 1669, the Illustrious School and with it the Hortus was closed down. It is possible that Stickers had connections with the Hortus, or even that he acquired plants from it in 1669, but there exists no cogent proof.

In or around Breda, Stickers must have made the acquaintance of Gédéon Bonivert, an officer in the army of Stadtholder William III. Bonivert was baptized on 19 March 1651 in Sedan, France, the son of Pasquet Bonivert, merchant, and Judith Bondot; his godparents were minister Gédéon Cheron and his wife. On 4 May 1699 Bonivert was naturalized as an English subject by an "Act of Denization". He died in 1703. The many campaigns that the army of the prince conducted in various coalitions against the France of Louis XIV were usually initiated from Breda. The Stadtholder owned a palace in this town. In 1690 Bonivert joined the campaign in Ireland against James II. Bonivert's diary contains a description of the battle of the Boyne.

In 1688-1689 William and his wife Mary Stuart had become King and Queen after a successful invasion and victory over Mary's father James. Bonivert was an amateur botanist, a hobby that he shared with many prominent members of the court: Hans Willem Bentinck and Gaspar Fagel in The Netherlands, and Bishop Henry Compton in England, to name but a few. Bonivert collected plants during his campaigns and preserved them in a herbarium. The plants which he collected in Ireland are the earliest herbarium specimens known from that country by about a decade; he donated them to Leonard Plukenet, the Queen's botanist. Bonivert collected also in Flanders. 
both in the wild and in gardens of amateurs. His herbarium later came into the possession of Hans Sloane, probably after Bonivert's death. Bonivert corresponded with this eminent scholar and with many other prominent English botanists, as welt as with the Royal Society. In The Netherlands, Bonivert also had good relations with professional botanists. He received plants from the Hortus of Leiden from Paul Hermann who was its director from 1680 until 1695. The difficulties in obtaining specimens from this garden are discussed by Heniger \& Sosef (1989).

Bonivert's herbarium is now included in the sumptuous herbarium of 265 bound volumes (the volume numbers go to 334) which Sloane bequeathed to the British nation and which is now kept in the British Museum (Natural History). It is contained in volumes 84,85 and 86 . Volume 84 of the Sloane Herbarium contains "Plants gathered in the fields and gardens of England, most of the garden of Leyden from Dr Herman . . ."; volume 85 has "Plants gathered by Mr Bonivert in Flanders, at

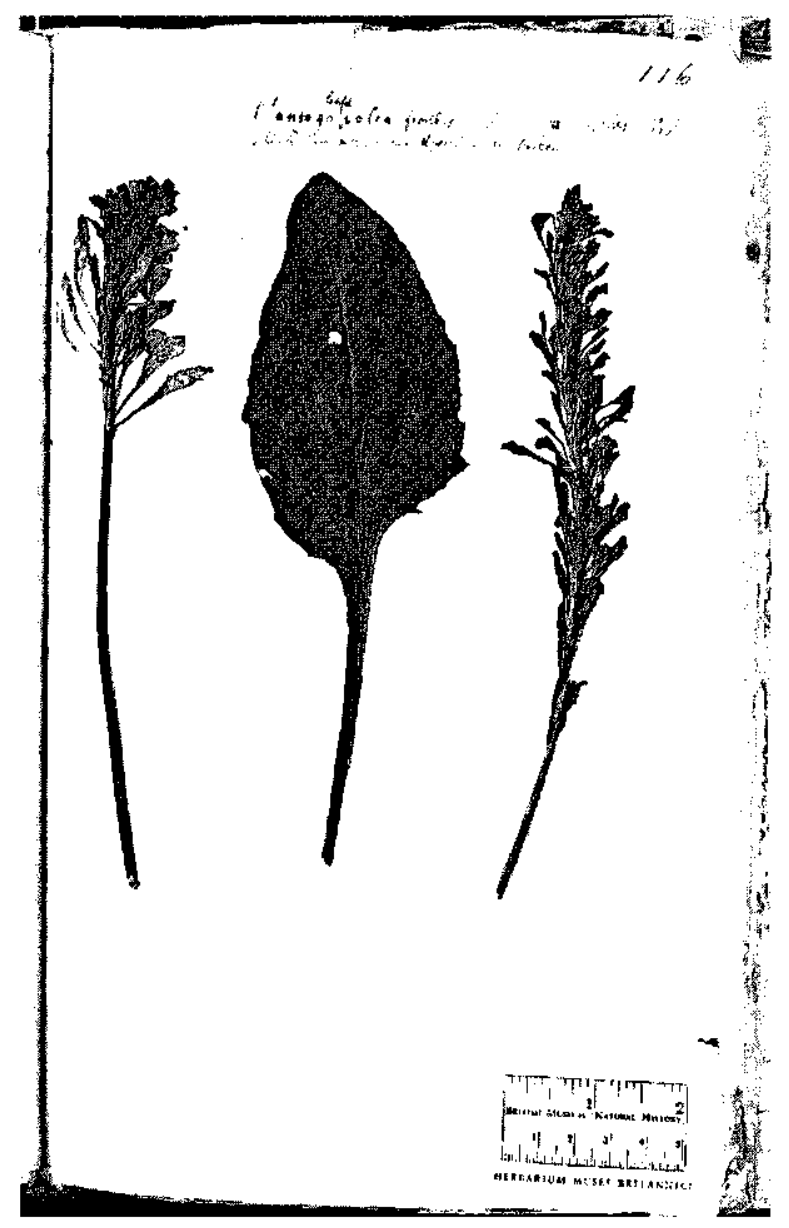

Figure 1. Plantago major L. 'Rosularis' in the Sloane Herbarium, British Museum (Natural History). 
Breda, and at the several Camps, wherein he was a lieutenant in the English Army", and volume 86 has "Plants gathered by $\mathrm{Mr}$ Bonivert in the fields and gardens of England, at Chelsea, etc." In volume 85 on folio 113 is a specimen of Aster Americanus multiflorus flore albo bellidis: disco luteo, nowadays Aster dumosus L., a Michaelmas Daisy from North America which in recent years has become popular as a cut flower. As stated on the label this species was also grown by "Domina de Flines", that is Agnes Blok (1629-1704) who grew plants in the "Vijverhof" at Loenen on the river Vecht. Tournefort in his Schola Botanica ascribed this plant name to her. Bonivert had his plant from "Dno Sticker in Breda". On folio 116 there is a specimen of Plantago latifollia] rosea floribus quasi in spica dispositis, a monstrous form of the plantain where small leaves are present in the spikes: Plantago major L. 'Rosularis'. This form is rarely grown nowadays, but around 1700 it was common in gardens. On the label is written "I had it from mr. Sticker Apothecary in Breda".

Neither the daisy nor the plantain were medicinal plants which Stickers would have grown for professional purposes. Stickers apparently also grew exotic plants for pleasure and so he is entitled to a minor place in the series of owners of private collection gardens in the seventeenth century. This has generally been overlooked as this information seems to come to us exclusively through the Bonivert herbarium.

\section{ACKNOWLEDGEMENTS}

Professor H.A. Bosman-Jelgersma drew my attention to Rehm's article on Johan Stickers. Dr P.F. Yeo kindly confirmed the determination of Aster dumosus. Biographical details on Bonivert were kindly provided by Dr H.A. Boeke at Noordwijk.

Dr C.E. Jarvis was of assistance with the Sloane Herbarium.

\section{REFERENCES}

BRITTEN, J., 1915 Gédéon Bonnivert (fl. 1673-1703). Journal of Botany 53: 107-112.

DANDY, J.E., 1958 The Sloane Herbarium. London.

HENIGER, J. \& M.S.M. SOSEF, 1989 Antoni Gaymans (ca 1630-1680) and his herbaria. Archives of Natural History 16: 147-168.

KUIJLEN, J., C.S. OLDENBURGER-EBBERS \& D.O. WIJNANDS, 1983 Paradisus Batavus. Bibliografie van plantencatalogi van onderwijstuinen, particuliere tuinen en kwekerscollecties in de Noordelijke en Zuidelijke Nederlanden (1550-1839). Wageningen: PUDOC.

REHM, G.J., 1960 De Bredase apothekers in de 15e-tot het begin van de 19e eeuw III. Bulletin No. 22. Kring voor de Geschiedenis van de Pharmacie in Benelux.

WIJNANDS, D.O., 1988 Hortus auriaci: the gardens of Orange and their place in late 17 th-century botany and horticulture. Journal of Garden History 8 (2\&3): 61-86. 